\title{
Evaluation of Pharmaceutical Care Standard Implementation in Medan City Health Center, North Sumatra
}

\section{Erviana N H, *, Wiryanto W, Harahap U.}

Department of Pharmacology, Faculty of Pharmacy, Universitas Sumatera Utara, Medan, 20155, Indonesia

\begin{abstract}
A B S T R A C T
Objectives: The implementation of Pharmaceutical Care Standards policies in health centers can be seen from the extent of suitability of human resources, facilities and infrastructure, management of medicines and consumable medical materials, clinical pharmacy care and quality control of pharmaceutical care. Inadequate implementation with the Pharmaceutical Care Standards policy will have a negative impact on service quality. This study aims to evaluate the implementation of Minister of Health Regulation No. 74 of 2016 concerning Pharmaceutical Care Standards in Medan City Health Center.

Methods: This research is a cross sectional descriptive survey research. Data obtained from filling out questionnaire sheets and checklist sheets based on direct observation in outpatient health centers that have pharmacists and pharmacy technical staff at the pharmacy. The data obtained were analyzed using indicators and compared with literature standards. This research was conducted in July - October 2019.

Results: The results showed that the total score of implementation of Pharmaceutical Care Standards in Medan City Health Center was 73-82 included in category II / moderate. Implementation has not yet fully met the standards, this is indicated by aspects of facilities and infrastructure; clinical pharmacy care have not been carried out effectively because it is related to the ratio between the number of patients with pharmacists and pharmaceutical technical personnel in the health center that is still not rational; and management of drugs and medical consumables. Assessment of the highest level of patient satisfaction is the Satisfaction category, as many as $77.89-97.87 \%$.

Conclusions: Implementation of Minister of Health Regulation No. 74 of 2016 concerning Pharmaceutical Care Standards in Medan City Health Center is included in the Medium Category. Factors affecting implementation include human resources and infrastructure. The level of patient satisfaction is Satisfied Category.
\end{abstract}

Keywords: policy implementation, pharmaceutical care standards, Regulation Minister of Health No 74, 2016

\begin{tabular}{ll}
\hline A R T I C L E I N F O: Received 25 Nov. 2019; Review Completed 21 Jan.2020; Accepted 27 Jan. 2020; & Available online 15 Feb. 2020 \\
Cite this article as: &
\end{tabular}

Erviana N H, Department of Pharmacology, Faculty of Pharmacy, Universitas Sumatera Utara, Medan, 20155, Indonesia

\section{INTRODUCTION}

$\mathrm{H}$ ealth effort is every activity to maintain and improve health, aiming to realize optimal health status for the community. Puskesmas is a basic health service facility that organizes health care efforts, health promotion (promotive), prevention of disease (preventive), cure of disease (curative), and recovery of health (rehabilitative), which is carried out thoroughly, integratedly, and continuously ${ }^{1}$.
So far, the implementation and implementation of health efforts in the basic policies of the existing Puskesmas vary greatly from region to region, but overall have not shown optimal results. Pharmaceutical care at the Puskesmas are an inseparable part of the implementation of health efforts, which play an important role in improving the quality of health services for the community ${ }^{1}$.

Pharmaceutical care is integrated activities aimed at identifying, preventing and resolving drug problems and problems related to health. Patient and community demands 
for improving the quality of Pharmaceutical care require an extension of the old product-oriented paradigm (drug oriented) to a new patient-oriented paradigm with a philosophy of Pharmaceutical care ${ }^{1}$.

As a benchmark and guideline for pharmaceutical workers in conducting pharmaceutical care at the Puskesmas, the Minister of Health issued a regulation namely Regulation Minister of Health No 74 of 2016concerning Pharmaceutical Care Standards at the Puskesmas. This study aims to evaluate the implementation of PMK No. 74 of 2016 in Medan City Health Center. One indicator that can be used in measuring the success rate of pharmaceutical care is by looking at the level of patient satisfaction. Patient satisfaction depends on the quality of services provided ${ }^{2}$.

\section{Method}

\section{Research Design}

This research is a cross sectional descriptive survey research. This research was conducted at an outpatient Community Health Center in Medan which had a pharmacist and pharmaceutical technical staff working at least 1 year. The data collected is primary and secondary data. Primary data were obtained from filling out questionnaire sheets and checklist sheets based on observations and interviews with Pharmacists and Puskesmas Heads. Secondary data was obtained from retrospective data collection by reviewing documents in 2019 relating to the management of pharmaceutical preparations and BMHP, clinical pharmacy services and quality control of pharmaceutical care in Medan City Health Center. The instrument filling data in the form of a checklist is adjusted to the literature standard. Patient Satisfaction Value is measured by Likert Scale ${ }^{3}$.

\section{Population}

Criteria for inclusion in the selection of Puskesmas are outpatient Puskesmas with pharmacy staff: Pharmacists and pharmacy technical personnel who have worked for at least 1 year.

There are 8 outpatient health centers in Medan that are included in the study inclusion criteria, including: Tegas Sari Health Center, DarussalamHealth Center, Kota MatsumHealth Center, SentosaBaruHealth Center, KampungBaruHealth Center, MandalaHealth Center, Padang BulanSelayangHealth Center, PadangBulanHealth Center.

The patient population is all patients who receive prescription drug services at the Puskesmas. The sampling technique uses Slovin calculations, with an error margin of $10 \%{ }^{4}$.

\section{Parameter Analysis}

The Standard Value of Pharmaceutical Care at the Puskesmas is measured according to the Training of Trainer Module (TOT) of pharmaceutical care at the puskesmas. The results of the total values obtained from filling in the checklist are grouped into categories with the appropriate range.

a. Category I with a total value of $>86$ is said to be Good b. Category II with a total value of $65-85$ is said to be Medium

c. Category III with a total value of $<65$ is said to be Less ${ }^{5}$.

\section{RESULTS AND DISCUSSION}

\section{Human Resources}

According to Regulation Minister of Health No 74 of 2016concerning pharmaceutical care standards at the Puskesmas it is stated that the pharmacy service provider at the Puskesmas must be done by at least one pharmacist as the person in charge and can be assisted by pharmaceutical technical personnel as needed. The number of pharmacists' needs at the puskesmas is calculated based on the ratio of patient visits both inpatient and outpatient as well as paying attention to the development of puskesmas. Ratio to determine the number of pharmacists at the puskesmas if possible one pharmacist is tried for a minimum of 50 patients a day ${ }^{1}$.

All pharmacy personnel must always improve their knowledge, skills and behavior in order to maintain and enhance their competence to provide quality pharmaceutical care to patients ${ }^{1}$.

In eight Medan city health centers where the research shows that pharmacy service providers have been carried out by pharmacists and pharmacy technical staff, the ratio between the number of patients and pharmacists and pharmacy technical personnel in the puskesmas is still not rational because the number of patient visits is more than 50 patients in a day.

All pharmacy workers in Medan City Health Center improve their knowledge and skills by attending seminars, workshops, and regular meetings held at the Medan City Health Office.

\section{Facilities and Infrastructure}

Based on PMK No.74 of 2016 on Pharmaceutical Care Standards at Puskesmas which state that the facilities needed to support pharmaceutical care at Puskesmas include facilities that have the function of receiving recipe space, prescription and compounding service space, drug delivery room, counseling room, storage room consumable drugs and medical materials, and archive space.

The facilities and infrastructure of the pharmaceutical space in the Medan City Health Center are still not fully up to standard. From the results of the data obtained shows that only 1 puskesmas already has complete facilities and infrastructure, while for 7 other puskesmas the facilities and infrastructure are already good to support pharmaceutical care, but there is no available counseling room for patients due to limited space and budget.

Counseling room is actually something that must exist in a health center, because effective counseling must consider the environment and the place of counseling, the environment in question must be conducive, safe and able to maintain confidentiality to be able to make patients receive information well.Adequate facilities and infrastructure will support the management process of drug management and pharmaceutical care and can improve overall pharmaceutical 
care, so that it becomes a major factor in achieving the goal of improving the quality of pharmaceutical services in puskesmas $^{6-7}$.

\section{Management of Pharmaceutical Preparations and Consumables}

Management of pharmaceutical sedans and consumable medical materials is one of the pharmaceutical care activities, which starts from planning, requesting, receiving, storing, distributing, controlling, recording, and reporting as well as monitoring and evaluation ${ }^{1}$.

The management of pharmaceutical preparations and consumable medical materials in Medan City Health Center is in accordance with PMK No. 74 of 2016 concerning Pharmaceutical Care Standards at the Health Center, only in one of the storage clinics the storage of pharmaceutical supplies and consumable medical materials does not meet the standards, because narcotics and psychotropic storage is not in accordance with statutory regulations, it is due to a communication error between the ordering party and the spice maker of the special narcotics and psychotropic cabinet.Storage of narcotics groups that are not placed in a special place certainly has the risk of loss and abuse of drugs. Storage of narcotics and psychotropic drugs is in need of strict security so as not to be misused by irresponsible persons.

Storage of Narcotics, Psychotropics, and Pharmaceutical Precursors in production facilities, distribution facilities and pharmaceutical care facilities must be able to maintain the safety, efficacy, and quality of Narcotics, Psychotropics, and Pharmaceutical Precursors. Special storage cabinets must meet the requirements, such as those made of strong material, and are not easily moved and have 2 (two) different keys ${ }^{8}$.

\section{Clinical Pharmacy Services}

Clinical pharmacy services are part of the pharmaceutical care that is direct and responsible for patients related to drugs to achieve definite results and to improve the quality of life of patients. Far service, the clinical services performed include: assessment and prescription services, drug information services, counseling, patient visits (specifically inpatient health centers), monitoring of drug side effects, monitoring of drug therapy, and evaluating use medicine ${ }^{1}$.

Based on the results of the study showed that in general clinical pharmacy services have not been performed optimally. For the implementation of Drug Information
Services it is still passive and limited. Drug information services which include making bulletins / leafleats / posters and outpatient counseling, have not been done well.

The next provisions that have not been fully implemented are counseling, monitoring of drug side effects, monitoring of drug therapy and evaluation of patient drug use in general have not been carried out according to standards, even though this is a process that ensures that a patient gets an effective and affordable drug therapy by maximizing efficacy and minimizing side effects ${ }^{1}$. In general, the constraints experienced in conducting clinical pharmacy services are in accordance with the standards, namely due to limited human resources, time and cost.

\section{Quality Control of Pharmaceutical Care}

From the results of the data obtained shows that overall the puskesmas already has an SOP reference to carry out pharmaceutical work, as well as make improvements and improve services according to standards. In implementing efforts to improve the quality of pharmaceutical care in accordance with the standards, the implementation of Pharmaceutical Care Standards is carried out in stages. This is to maintain consistency in the implementation of pharmaceutical care standards. Ongoing evaluation for improvement of pharmaceutical care at the puskesmas by the Health Service is conducted once a year, and for special programs the services are carried out every month to three months.

\section{Results of Calculation of Pharmaceutical Care Standards}

Puskesmas pharmacy service standards are calculated based on the total score of human resources, facilities and infrastructure, management of pharmaceutical preparations and consumable medical materials, clinical pharmacy services and quality control of pharmaceutical care. The total score obtained for the Medan City Health Center was 73-82. Based on the results of the total score obtained states that the standard of pharmacy services in Medan City Health Center is included in the category II / moderate.

\section{Level of Patient Satisfaction}

Patient satisfaction depends on the quality of service. A service is said to be good by the patient, determined by the fact whether the services provided can meet the needs of patients, by using patient perceptions about the services received (satisfying or disappointing) ${ }^{2}$. The distribution of patient satisfaction levels can be seen in Table 1.

Table 1: Patient Satisfaction Data

\begin{tabular}{|c|c|c|c|c|c|c|c|c|c|c|c|c|c|c|c|c|}
\hline \multirow{2}{*}{$\begin{array}{l}\text { Patient } \\
\text { Satisfaction }\end{array}$} & \multicolumn{2}{|l|}{$\mathrm{TS}$} & \multicolumn{2}{|c|}{ KM } & \multicolumn{2}{|l|}{ KB } & \multicolumn{2}{|c|}{ PB S } & \multicolumn{2}{|l|}{$\mathrm{D}$} & \multicolumn{2}{|l|}{ SB } & \multicolumn{2}{|l|}{$\mathrm{M}$} & \multicolumn{2}{|l|}{ PB } \\
\hline & $\begin{array}{l}n= \\
94\end{array}$ & $\%$ & $\begin{array}{l}\mathrm{n}= \\
92\end{array}$ & $\%$ & $\begin{array}{l}\mathrm{n}= \\
93\end{array}$ & $\%$ & $\begin{array}{l}\mathrm{n}= \\
95\end{array}$ & $\%$ & $\begin{array}{l}n= \\
96\end{array}$ & $\%$ & $\begin{array}{l}\mathrm{n}= \\
96\end{array}$ & $\%$ & $\begin{array}{l}\mathrm{n}= \\
95\end{array}$ & $\%$ & $\begin{array}{l}\mathrm{n}= \\
96\end{array}$ & $\%$ \\
\hline Not Satisfied & 0 & 0 & 0 & 0 & 0 & 0 & 0 & 0 & 0 & 0 & 0 & 0 & 0 & 0 & 0 & 0 \\
\hline Satisfied & 92 & 97,87 & 76 & 82,61 & 84 & 90,32 & 90 & 94,74 & 89 & 92,71 & 85 & 88,54 & 74 & 77,89 & 89 & 92,71 \\
\hline Very Satisfied & 2 & 2,13 & 16 & 17,39 & 9 & 9,68 & 5 & 5,26 & 7 & 7,29 & 11 & 11,46 & 21 & 22,11 & 7 & 7,29 \\
\hline
\end{tabular}


Based on Table 1 shows that respondents rated satisfaction with pharmaceutical care with the highest rating, namely Satisfaction Category with the highest percentage of $97.87 \%$ Tegal Sari puskesmas, while respondents who rated satisfaction with the Very Satisfied Category with the highest percentage of $22.11 \%$ Mandala puskesmas. Patient satisfaction is influenced by the quality of service received by the patient.

\section{CONCLUSION}

The results showed that the implementation of Regulation Minister of Health No. 74 of 2016concerning Pharmaceutical Care Standards in Medan City Health Center included in the Medium Category. Factors affecting implementation include human resources and infrastructure. The level of patient satisfaction is Satisfied Category.

\section{ACKNOWLEDGMENT}

The researcher gives her gratitude to the Medan City Health Office, North Sumatra for this study.

\section{REFERENCES}

1. Menkes RI. PeraturanMenteriKesehatan RI Nomor 74 Tahun 2016 TentangStandarPelayananKefarmasian Di Puskesmas. Jakarta. MenteriKesehatan RI. 2016: 3-33.

2. Supriyanto\&Ernawaty. PemasaranIndustriJasaKesehatan. Yogyakarta. Andi. 2010.

3. Hermawan, A danYusran, H. 2017. PenelitianBisnisPendekatanKuantitatif. EdisiPertama. Kencana. Halaman: 6, 87, 97.

4. Gunawan, F. SenaraiPenelitianPendidikan, Hukum, danEkonomi di Sulawesi Tenggara. Yogyakarta. Deepublish. 2018: 12.

5. Menkes RI. Modul TOT PelayananKefarmasian di Puskesmas. DirektoratJenderalBinaKefarmasiandanAlatKesehatan. Jakarta. DepartemenKesehatan RI. 2008: 65-75.

6. Yuniarti, R. ImplementasiPeraturanMenteriKesehatan No 30 Tahun 2014 TentangStandarPelayananKefarmasian di Puskesmas di Kabupaten Bengkulu Utara. Tesis. FakultasKedokteran. Universitas Gajah Mada. 2017; 2-6, 40-68.

7. Agustino, L. Dasar-DasarKebijakanPublik. Bandung: Alfabeta.2014.

1. Menkes RI. PeraturanMenteriKesehatanRepublik Indonesia Nomor 3 Tahun 2015 TentangPeredaran, Penyimpanan, Pemusnahan, danPelaporanNarkotika, Psikotropika, danPrekursorFarmasi Jakarta. MenteriKesehatan RI. 2011; 14-15. 